\title{
Targeting dendritic cells in pancreatic ductal adenocarcinoma
}

\author{
Anton Deicher ${ }^{1,2}$, Roland Andersson ${ }^{1}$, Bobby Tingstedt ${ }^{1}$, Gert Lindell ${ }^{1}$, Monika Bauden ${ }^{1}$ and Daniel Ansari ${ }^{{ }^{*}}$ (1)
}

\begin{abstract}
Dendritic cells (DC) are an integral part of the tumor microenvironment. Pancreatic cancer is characterized by reduced number and function of DCs, which impacts antigen presentation and contributes to immune tolerance. Recent data suggest that exosomes can mediate communication between pancreatic cancer cells and DCs. Furthermore, levels of DCs may serve as prognostic factors. There is also growing evidence for the effectiveness of vaccination with DCs pulsed with tumor antigens to initiate adaptive cytolytic immune responses via T cells. Most experience with DC-based vaccination has been gathered for MUC1 and WT1 antigens, where clinical studies in advanced pancreatic cancer have provided encouraging results. In this review, we highlight the role of DC in the course, prognosis and treatment of pancreatic cancer.
\end{abstract}

Keywords: Pancreatic cancer, Dendritic cells, Antigen presenting cell, Immunotherapy, Vaccine

\section{Background}

Ductal adenocarcinoma of the pancreas has the highest mortality rate amongst all major human tumors [1]. Due to the insidious nature of the disease, approximately $85 \%$ of patients have advanced disease at presentation. Survival rates have remained stagnant in the last decades and there is a lack of early detection tools and effective treatment [2]. In Europe, the median survival for pancreatic cancer is 4.6 months and only $3 \%$ of patients survive beyond 5 years [3]. Metastatic pancreatic cancer confers an especially poor prognosis and treatment progress has been slow. Multiagent chemotherapy has been shown to prolong survival by a few weeks to a couple of months, but toxicity remains a challenge and it is still difficult to identify responders to treatment [4]. There is an urgent need to develop new types of therapy based on individual tumor genotype/phenotype in order to increase survival rates and reduce overtreatment.

Traditionally, immunotherapy has had little success in solid tumors. However, recent progress in immunooncology, especially in melanoma and renal cancer, has

\footnotetext{
*Correspondence: daniel.ansari@med.lu.se

1 Department of Surgery, Clinical Sciences Lund, Lund University

and Skåne University Hospital, 22185 Lund, Sweden

Full list of author information is available at the end of the article
}

revitalized the concept of harnessing the patient's own immune system against the tumor [5]. Recent molecular mapping has revealed an immunogenic subtype of pancreatic cancer that may be targetable through immune treatment [6]. Furthermore, extensive immunoprofiling has shown that long-term survivors of pancreatic cancer are characterized by improved neoantigen quality and enhanced immune response [7].

Dendritic cells (DC) are professional antigen-presenting cells at the intersection of innate and adaptive immunity, initiating, directing and modulating immune responses. DCs are described as a heterogeneous population to match a variety of microenvironmental conditions [8]. Here, we review the role of DCs in the development, progression and potential therapy of pancreatic cancer.

\section{Paucity of dendritic cells in pancreatic cancer}

Immune escape is one of the hallmarks of cancer [9]. Antigen presentation by DCs is essential to effective antitumor $\mathrm{T}$ cell responses. DCs are rare in the pancreatic tumor microenvironment and the cells are located at the edges of the tumor [10]. Systemically, decreased levels of blood DCs have been demonstrated in patients with pancreatic cancer [11]. Of note, increased circulating levels of DCs have been associated with better survival in patients with pancreatic cancer [11-13]. Furthermore, 
surgical removal of the pancreatic tumor was shown to improve blood DC function, supporting a tumor-derived influence on immune function [14].

Chronic pancreatitis is a major risk factor for pancreatic cancer. However, the molecular mechanisms bridging these entities are not well understood. It has been postulated that chronic inflammation not only promotes tumor development through the release of e.g. growth factors, but also indirectly by impairing the ability of DCs to activate immune responses against the tumor [11].

\section{Mechanisms of dendritic cell suppression}

The host immune reaction to pancreatic cancer is reported to change from immune surveillance to immune tolerance during disease progression. This is mediated by CXCL17 and ICAM2 [15]. Furthermore, tumor-derived cytokines, such as TGF-beta, IL-10, and IL-6, have been reported to suppress DC survival and proliferation [16]. Expansion of immature myeloid cells in the circulation as well as the spleen might further compromise the immune response. Levels of circulating myeloid derived suppressive cells (MDSCs) have been reported to be increased in pancreatic cancer, which may promote tumor progression $[17,18]$. MDSCs produce nitric oxide (NO) and inhibit DC activation in pancreatic cancer [19].

\section{Subpopulations of dendritic cells}

DC can differentiate into distinct subpopulations depending on microenvironmental stimuli, leading to proliferation of myeloid DCs that induce Th1 cell activation or plasmacytoid DCs that facilitate immunosuppressive $\mathrm{T}$ cell development. Tumor-derived cytokines have been reported to induce a tolerogenic plasmacytoid DC phenotype [16]. Furthermore, recent data suggest the existence of a specific subset CD11b ${ }^{+}$DCs that establish an immunosuppressive microenvironment, which favors metastatic progression through the expansion of regulatory $\mathrm{T}$ cells (Tregs) and suppression of CD8+ T cells [20]. These findings indicate that pancreatic cancer is characterized not only by reduced numbers of DCs, but also a complex modulation of DC subpopulations, which affects tumor development.

\section{Maturation of dendritic cells}

Defective maturation of DCs may contribute to the development of a tumor-tolerant immune status. It has been found that semi mature blood DCs exist in pancreatic cancer patients, likely mediated by inflammatory factors released from the tumor [21]. These DCs have lost their ability to act as professional antigen presenting cells and activate $\mathrm{T}$ cell responses, and this leads to suppression of adaptive immune responses.

\section{Aberrant antigen presentation}

Altered antigen processing and presentation is an important mechanism by which cancers evade the immune system. Pancreatic tumors are characterized by a loss or down-regulation of antigen-processing and antigen presenting molecules, including the human leucocyte antigen (HLA) class I and transporter for antigen presentation (TAP). Reduction of HLA class I expression was observed in $76 \%$ of pancreatic cancer cases and $53 \%$ of cases had reduced TAP expression [22].

\section{Crosstalk between pancreatic cancer cells and dendritic cells}

Exosomes are nanovesicles of endocytic origin that are released by many cell types into the extracellular microenvironment. Exosomes contain proteins, mRNAs, microRNAs and lipids and play a central role in intercellular communication [23]. Pancreatic cancer cells and DCs release exosomes that influence the tumor-immune function. In a mathematical model, it was reported that pancreatic cancer cells shed exosomes that inhibit immune responses by DCs, while DCs secrete exosomes that induce apoptosis of pancreatic cancer cells [24]. A previous study revealed that pancreatic cancer-derived exosomes attenuate DC-mediated tumor suppressive responses initiated by TLR4 [25]. Furthermore, pancreatic cancer-derived exosomes have been shown to inhibit regulatory factor $\mathrm{X}$-associated protein expression through miR-212-3p. This may result in decreased expression of major histocompatibility complex (MHC) II and lead to immune tolerance of DCs [26]. Thus, tumorderived exosomes regulate host immunosuppression by influencing the function and differentiation of DCs [27].

\section{Prognostic role of dendritic cells}

The numbers of circulating DCs have been found to be an independent prognostic factor for prolonged survival in pancreatic cancer $[12,13]$. However, distinct subsets of DCs may have diverging prognostic potential. For example, an increased level of immune tolerant immature DCs were shown to result in shorter survival [28].

\section{Treatment with dendritic cell-based vaccines}

The basic idea of tumor vaccination is to confront (pulse) antigen presenting cells such as DCs with tumor-associated antigens to achieve presentation and thereby induce cytotoxic T cells. Different methods exist to pulse DCs: (a) synthetic peptides or purified proteins, (b) DNA, RNA or viruses (transfection), (c) tumor lysates or autophagosomes or (d) fusing tumor cells with DC (Fig. 1).

The use of peptides, DNA or RNA as a pulsation media results in a highly specific immune response. However, 


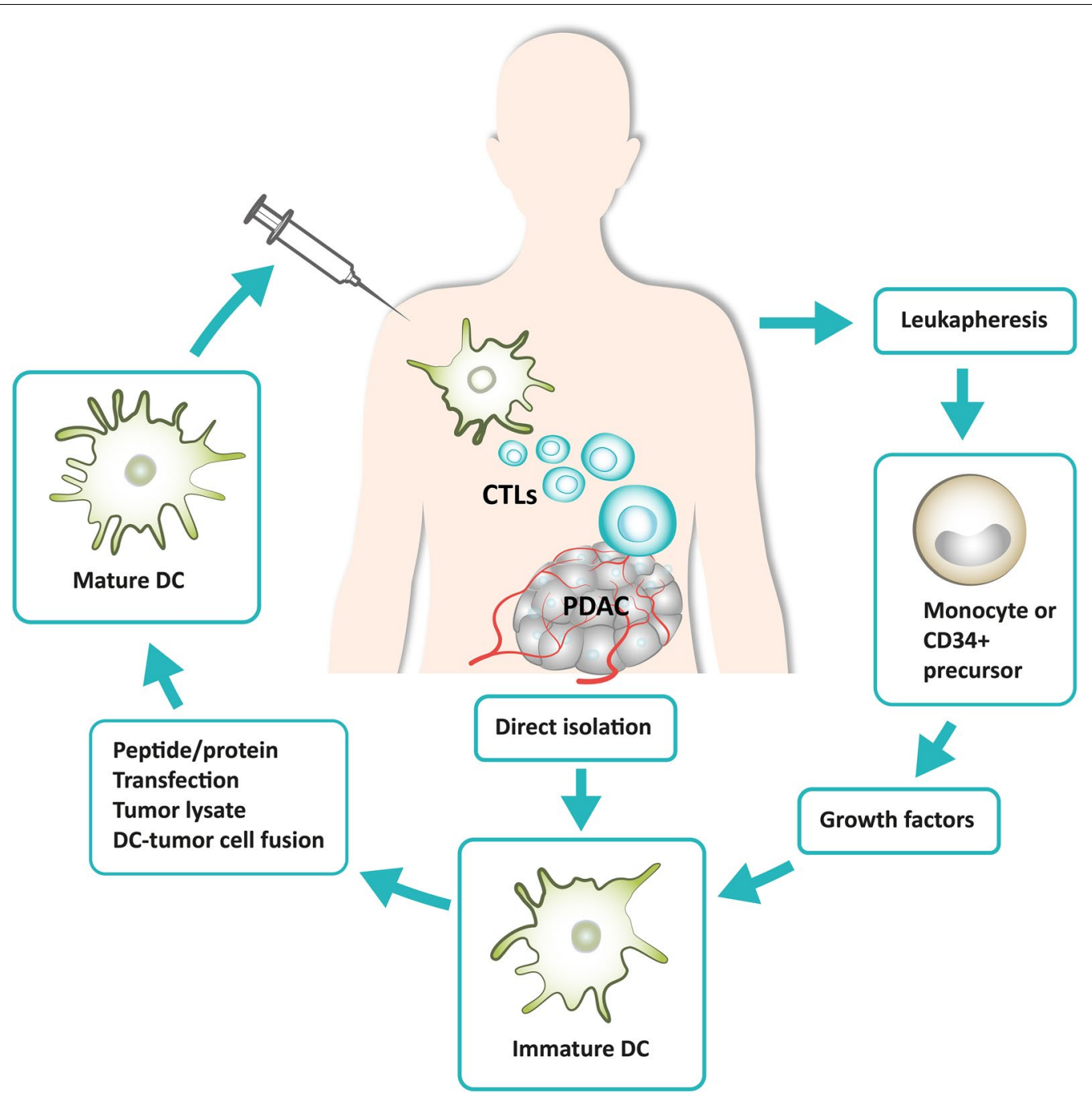

Fig. 1 Principles of dendritic cell-based immunotherapy in pancreatic cancer, including extraction, priming and re-injection of dendritic cells. CTL cytotoxic T lymphocyte, DC, dendritic cell, PDAC pancreatic ductal adenocarcinoma

the applicable antigens need to be present in the patient, which reduces the range of treatable cases and requires genetic/proteomic analyses. Even so, a risk of cross-reactivity remains. Furthermore, peptides are restricted to a specific antigen presenting HLA molecule, which in turn narrows the number of benefiting patients. Genomic media allows for a broader selection of presenting HLA molecules and might therefore benefit a wider range of patients. However, (c)DNA requires entry into the nucleus and RNA is unstable, which are known limitations [29].

Tumor lysates allow for a broad selection of tumor associated antigens (TAAs) and thereby a more comprehensive tumor attack. However, the exact mechanisms and target structures of this method often remain unclear, and the risk of cross reactivity might be high.
Fusion of tumor cells with DCs is an interesting method to improve tumor antigen presentation. The approach also results in a wide range of presented antigens, but clinical studies are necessary to assess efficacy.

\section{Tumor associated antigens in pancreatic cancer}

To date, different TAAs in pancreatic cancer have been discovered and are currently under investigation. Despite mostly having been investigated in vitro or in animal models, the first clinical data are already present (Table 1).

\section{MUC1}

MUC1 is a glycoprotein that is expressed in nearly all pancreatic cancers [30]. Transfected DCs with liposomal MUC1 cDNA were evaluated as a vaccine in 10 patients 
Table 1 Published series on dendritic cell-based immunotherapy in pancreatic cancer

\begin{tabular}{|c|c|c|c|c|c|c|c|c|}
\hline Tumor-associated antigen & Year & $\mathrm{N}^{\mathrm{a}}$ & Stage & Pulsation & $\mathbf{R}$ & SD & PD & $\begin{array}{l}\text { Median } \\
\text { survival } \\
\text { (months) }\end{array}$ \\
\hline \multicolumn{9}{|l|}{ MUC1 } \\
\hline Pecher et al. [31] & 2002 & 2 & Unresectable & cDNA & & 0 & 2 & \\
\hline Kondo et al. [32] & 2008 & 20 & Unresectable & Peptide & 1 & 5 & 14 & $9.8^{b}$ \\
\hline Lepisto et al. [33] & 2008 & 12 & Resectable & Peptide & 4 & & & 26 \\
\hline Rong et al. [34] & 2012 & 7 & Unresectable & Peptide & & 0 & 7 & \\
\hline Shindo et al. [35] & 2014 & 42 & Unresectable & mRNA & 4 & 22 & 16 & 13.9 \\
\hline \multicolumn{9}{|l|}{ WT1 } \\
\hline Koido et al. [37] & 2014 & 10 & Unresectable & Peptide & & 7 & 3 & \\
\hline Takakura et al. [39], Tsukinaga et al. [40] & 2015 & 7 & Unresectable & Peptide & & 6 & 1 & 10.8 \\
\hline Mayanagi et al. [38] & 2015 & 10 & Unresectable & Peptide & & 6 & 4 & 8.3 \\
\hline Okamoto et al. [41] & 2016 & 255 & Unresectable & Peptide & & & & 9.9 \\
\hline \multicolumn{9}{|l|}{ Mesothelin } \\
\hline Thomas et al. [43] & 2004 & 14 & Unresectable & Peptide & \multicolumn{4}{|c|}{ Immunological response in 3 patients } \\
\hline \multicolumn{9}{|l|}{ KRAS } \\
\hline Gjertsen et al. [45] & 1996 & 5 & Unresectable & Peptide & & 3 & 2 & 5 \\
\hline \multicolumn{9}{|l|}{ hTERT, CEA, survivin } \\
\hline Mehrotra et al. [55] & 2017 & 12 & Unresectable & Peptide & & & & 7.7 \\
\hline \multicolumn{9}{|l|}{ CEA, HER2, WT1 } \\
\hline Kimura et al. [56] & 2012 & 49 & Unresectable & Peptide & 7 & 10 & 32 & 11.8 \\
\hline \multicolumn{9}{|l|}{ CEA, MUC1 } \\
\hline Nakamura et al. [59] & 2009 & 12 & Unresectable & Peptide, lysate & & & & 9 \\
\hline \multicolumn{9}{|l|}{ Tumor cell lysate } \\
\hline Bauer et al. [61] & 2011 & 12 & Unresectable & Lysate & 1 & 2 & 9 & 10.5 \\
\hline
\end{tabular}

with metastatic breast, pancreatic and ampullary cancer [31]. The study showed the feasibility and toleration of tumor vaccination and reported an increased cytotoxic T-lymphocyte (CTL) response in the pancreatic cancer patients. The clinical benefit of MUC1-DCs and MUC1CTLs was evaluated in 20 patients with unresectable or recurrent pancreatic cancer. Complete response was noted in 1 patient, and stable disease noted in 5 patients. The mean survival was 9.8 months [32]. Another study evaluated the clinical efficacy of a MUC1 peptide-loaded DC vaccine in 12 pancreatic and biliary cancer patients following surgical resection. The vaccine was well tolerated and no toxicity was observed. Four vaccinated patients are alive up to 5 years after surgery [33]. MUC1peptide-pulsed DCs were evaluated in the treatment of 7 patients with metastatic or recurrent pancreatic cancer. The vaccination was well tolerated and capable of inducing immunological response, but no clinical benefit was noted [34]. Combination therapy using MUC1-mRNAtransfected DCs, MUC1-CTLs and gemcitabine was evaluated in 42 patients with unresectable or recurrent pancreatic cancer. Mean survival was 13.9 months. Patients who received high dose MUC1-DCs and MUC1CTLs had significantly enhanced survival (16.5 months vs 5.7 months; $\mathrm{p}<0.001)$ [35]. These data suggest that MUC1 is a promising TAA, considering both the reported feasibility and to some extend the effectiveness of DC-based MUC-1 specific immunotherapy.

\section{WT1}

Wilms tumor gene (WT1) encodes a zinc finger transcription factor that plays an important role in cell growth and differentiation. The WT1 protein is highly expressed (75\%) in pancreatic cancers [36]. Treatment with DCs pulsed with WT1 peptides and chemotherapy in advanced pancreatic cancer has been evaluated in several small series from Japan [37-40]. The protocol was subsequently presented as a retrospective, multicenter analysis including 255 patients [41]. The median overall survival from diagnosis was 16.5 months and 9.9 months following treatment with standard chemotherapy combined with peptide-pulsed DC vaccines. The median 
survival time of the patients with positive delayed type hypersensitivity skin reaction was significantly prolonged compared to that of the patients with negative reaction $(p=0.015)$. These findings based on WT1-specific immunotherapy are promising, but more research is needed to stratify patient and determine responders.

\section{Mesothelin}

Mesothelin has been found to be overexpressed in the majority of pancreatic tumors, with a detection rate ranging from 60 to $100 \%[30,42]$. A vaccine with allogeneic GM-CSF-secreting pancreatic tumor cell lines was found to induce delayed type hypersensitivity responses in 3 out of 14 treated pancreatic cancer patients [43]. The vaccine was found to recruit DCs to the site of vaccination and stimulate CD8 $+\mathrm{T}$ cells by a cross-priming mechanism involving mesothelin.

\section{KRAS}

KRAS is mutated in more than $90 \%$ of pancreatic cancer and is a central driver of pancreatic tumor growth and progression [44]. Synthetic RAS peptide has been used as a vaccine in 5 patients with advanced pancreatic carcinoma. An immune response against the immunizing RAS peptide could be induced in 2 patients [45]. The median survival was 10.5 months for the 2 responding patients, compared to 4.5 months for the non-responding patients. Most KRAS mutations in pancreatic cancer are located in codon 12, while mutations in codon 13 and 61 are much less common [46]. Development of new vaccine protocols that target the individual patient's specific RAS mutation may further improve immunogenicity and ultimately prove clinically beneficial.

\section{Other antigens}

Other peptides and proteins have been used to pulse DCs in order to induce a tumor-specific immune response. CA 19-9 is a classic tumor marker, present in approximately $80 \%$ of pancreatic cancer patients [47]. It has been found that DCs pulsed with the CA 19-9 protein or CA 19-9 containing serum have the ability to induce cytotoxic activity against pancreatic cancer cells in vitro $[48,49]$. Further preclinical data support the immunogenic potential of Trop2 [50], MUC-4 [51], pathological bile salt-dependent lipase (pBSDL) $[52,53]$ and $\alpha$-Enolase [54]. In patients, human telomerase reverse transcriptase (hTERT) [55], carcinoembryonic antigen (CEA) [55-57], survivin [55], HER2 [56, 57], CA-125 [56] and $\alpha$-fetoprotein [57] have also been tested in small series. Most of these antigens have been tested in a combinatorial approach using multiple peptides as targets for DC-based vaccination. This is a promising approach, which addresses the problem of impaired range of targets in peptide-, DNA- or RNA-based vaccination protocols. However, there is also need to compare the efficacy of individual peptides.

\section{Tumor cell lysate}

In addition to the use of peptides as pulsation substance, lysed tumor cells can be used. Tumor lysate can be generated by multiple freeze-thaw cycles or UV-irradiation of tumor cells. The potential benefits include a broader selection of TAAs and thereby a more comprehensive tumor attack, but the exact mechanisms and target structures of this method often remain unclear. Also, it cannot be excluded that non-tumor-specific antigens are expressed by DCs within this method, resulting in crossor auto-reactive CTLs [58]. Nonetheless, whole tumorlysate for pulsing DCs has been shown to be feasible, safe and potentially beneficial as a vaccination-method in pancreatic cancer [59-62]. This strategy provides a reproducible pool of most tumor antigens suitable for patient use, independent of MHC haplotypes or autologous tumor tissue availability. However, optimizing autologous tumor cell lysate preparation is crucial in order to enhance efficacy.

\section{Cellular fusion}

Fusion of DCs with pancreatic tumor cells potentially acts synergistically to improve antigenicity and antigen presentation in order to induce tumor-specific cytotoxic immunity. So far, most data using these cellular hybrids have been reported in experimental settings of pancreatic cancer [63-65].

\section{Conclusion}

Pancreatic cancer is associated with an immune tolerant state, which is mediated by a complex shift in the number, phenotype and function of multiple immune cells, including DCs. Subpopulations of DCs are altered in pancreatic cancer related to effects by the tumor cells as well as the microenvironment. Pulsation of DCs with a wide range of antigens has been shown to be effective in initiating adaptive, antigen-specific immune responses, but there remain many unresolved questions. For example, more research needs to be conducted into the optimal sequence and interval of vaccination, the role of immune adjuncts and the potential synergies with conventional treatment such as surgery, chemotherapy and radiation. In the future, the use of novel vaccine protocols based on the individual patient's tumor phenotype may lead to long-term clinical benefit.

\section{Abbreviations}

DC: dendritic cell; HLA: human leucocyte antigen; MDSC: myeloid derived suppressor cell; MHC: major histocompatibility complex; MUC1: mucin 1; TAA 
: tumor associated antigen; TAP: transporter for antigen presentation; Treg: regulatory T cell; WT1: Wilms tumor 1 .

\section{Authors' contributions}

AD performed the literature review and wrote the first draft. BT, GL and RA participated in clinical data interpretation and manuscript editing. MB assisted in experimental data interpretation. DA conceived the study, assisted in manuscript writing and provided overall supervision for the work. All authors read and approved the final manuscript.

\section{Author details}

${ }^{1}$ Department of Surgery, Clinical Sciences Lund, Lund University and Skåne University Hospital, 22185 Lund, Sweden. ${ }^{2}$ Faculty of Medicine, RuprechtKarls-Universität Heidelberg, Heidelberg, Germany.

\section{Acknowledgements}

Not applicable.

\section{Competing interests}

The authors declare that they have no competing interests.

\section{Availability of data and materials}

All data generated or analyzed during this study are included in this published article.

\section{Consent for publication}

Not applicable.

\section{Ethics approval and consent to participate}

Not applicable.

\section{Funding}

The study was supported by SWElife/Ninnova, the Royal Physiographic Society of Lund, the Magnus Bergvall Foundation, the Tore Nilsson Foundation, the Inga and John Hain Foundation for Medical Research and the Crafoord Foundation. The funding bodies had no role in study design, data collection/ analysis/interpretation or manuscript preparation.

\section{Publisher's Note}

Springer Nature remains neutral with regard to jurisdictional claims in published maps and institutional affiliations.

Received: 12 February 2018 Accepted: 12 June 2018

Published online: 18 June 2018

\section{References}

1. Siegel RL, Miller KD, Jemal A. Cancer statistics, 2017. CA Cancer J Clin. 2017;67(1):7-30.

2. Ansari D, Tingstedt B, Andersson B, Holmquist F, Sturesson C, Williamsson C, Sasor A, Borg D, Bauden M, Andersson R. Pancreatic cancer: yesterday, today and tomorrow. Future Oncol. 2016;12(16):1929-46.

3. Carrato A, Falcone A, Ducreux M, Valle JW, Parnaby A, Djazouli K, AlnwickAllu K, Hutchings A, Palaska C, Parthenaki I. A systematic review of the burden of pancreatic cancer in Europe: real-world impact on survival, quality of life and costs. J Gastrointest Cancer. 2015;46(3):201-11.

4. Lee HS, Park SW. Systemic chemotherapy in advanced pancreatic cancer. Gut Liver. 2016;10(3):340-7.

5. Menon S, Shin S, Dy G. Advances in cancer immunotherapy in solid tumors. Cancers. 2016;8(12):106.

6. Bailey P, Chang DK, Nones K, Johns AL, Patch AM, Gingras MC, Miller DK, Christ AN, Bruxner TJ, Quinn MC, et al. Genomic analyses identify molecular subtypes of pancreatic cancer. Nature. 2016;531(7592):47-52.

7. Balachandran VP, Luksza M, Zhao JN, Makarov V, Moral JA, Remark R, Herbst B, Askan G, Bhanot U, Senbabaoglu Y, et al. Identification of unique neoantigen qualities in long-term survivors of pancreatic cancer. Nature. 2017:551(7681):512-6.

8. Boltjes A, van Wijk F. Human dendritic cell functional specialization in steady-state and inflammation. Front Immunol. 2014;5:131.
9. Hanahan D, Weinberg RA. Hallmarks of cancer: the next generation. Cell. 2011;144(5):646-74.

10. Dallal RM, Christakos P, Lee K, Egawa S, Son Yl, Lotze MT. Paucity of dendritic cells in pancreatic cancer. Surgery. 2002;131(2):135-8.

11. Tjomsland V, Sandstrom P, Spangeus A, Messmer D, Emilsson J, Falkmer U, Falkmer S, Magnusson KE, Borch K, Larsson M. Pancreatic adenocarcinoma exerts systemic effects on the peripheral blood myeloid and plasmacytoid dendritic cells: an indicator of disease severity? BMC Cancer. 2010;10:87.

12. Hirooka S, Yanagimoto H, Satoi S, Yamamoto T, Toyokawa H, Yamaki S, Yui R, Inoue K, Michiura T, Kwon AH. The role of circulating dendritic cells in patients with unresectable pancreatic cancer. Anticancer Res. 2011;31(11):3827-34

13. Yamamoto T, Yanagimoto $\mathrm{H}$, Satoi S, Toyokawa H, Yamao J, Kim S, Terakawa N, Takahashi K, Kwon AH. Circulating myeloid dendritic cells as prognostic factors in patients with pancreatic cancer who have undergone surgical resection. J Surg Res. 2012;173(2):299-308.

14. Takahashi K, Toyokawa H, Takai S, Satoi S, Yanagimoto H, Terakawa N, Arak $\mathrm{H}$, Kwon AH, Kamiyama Y. Surgical influence of pancreatectomy on the function and count of circulating dendritic cells in patients with pancreatic cancer. Cancer Immunol Immunother. 2006;55(7):775-84.

15. Hiraoka N, Yamazaki-Itoh R, Ino Y, Mizuguchi Y, Yamada T, Hirohashi S, Kanai Y. CXCL17 and ICAM2 are associated with a potential anti-tumor immune response in early intraepithelial stages of human pancreatic carcinogenesis. Gastroenterology. 2011;140(1):310-21.

16. Bellone G, Carbone A, Smirne C, Scirelli T, Buffolino A, Novarino A, Stacchini A, Bertetto O, Palestro G, Sorio C, et al. Cooperative induction of a tolerogenic dendritic cell phenotype by cytokines secreted by pancreatic carcinoma cells. J Immunol. 2006;177(5):3448-60.

17. Basso D, Fogar P, Falconi M, Fadi E, Sperti C, Frasson C, Greco E, Tamburrino D, Teolato S, Moz S, et al. Pancreatic tumors and immature immunosuppressive myeloid cells in blood and spleen: role of inhibitory co-stimulatory molecules PDL 1 and CTLA4. An in vivo and in vitro study. PLoS ONE. 2013;8(1):e54824.

18. Karakhanova S, Link J, Heinrich M, Shevchenko I, Yang Y, Hassenpflug M, Bunge $\mathrm{H}$, von Ahn K, Brecht R, Mathes A, et al. Characterization of myeloid leukocytes and soluble mediators in pancreatic cancer: importance of myeloid-derived suppressor cells. Oncoimmunology. 2015;4(4):e998519.

19. Markowitz J, Wang J, Vangundy Z, You J, Yildiz V, Yu L, Foote IP, Branson $\mathrm{OE}$, Stiff AR, Brooks TR, et al. Nitric oxide mediated inhibition of antigen presentation from DCs to CD4(+) T cells in cancer and measurement of STAT1 nitration. Sci Rep. 2017:7(1):15424.

20. Kenkel JA, Tseng WW, Davidson MG, Tolentino LL, Choi O, Bhattacharya N, Seeley ES, Winer DA, Reticker-Flynn NE, Engleman EG. An immunosuppressive dendritic cell subset accumulates at secondary sites and promotes metastasis in pancreatic cancer. Cancer Res. 2017;77(15):4158-70.

21. Tjomsland V, Spangeus A, Sandstrom P, Borch K, Messmer D, Larsson M. Semi mature blood dendritic cells exist in patients with ductal pancreatic adenocarcinoma owing to inflammatory factors released from the tumor. PLOS ONE. 2010;5(10):e13441

22. Pandha H, Rigg A, John J, Lemoine N. Loss of expression of antigenpresenting molecules in human pancreatic cancer and pancreatic cancer cell lines. Clin Exp Immunol. 2007;148(1):127-35.

23. Azmi AS, Bao B, Sarkar FH. Exosomes in cancer development, metastasis, and drug resistance: a comprehensive review. Cancer Metastasis Rev. 2013;32(3-4):623-42.

24. Friedman A, Hao W. The role of exosomes in pancreatic cancer microenvironment. Bull Math Biol. 2018;80(5):1111-33.

25. Zhou M, Chen J, Zhou L, Chen W, Ding G, Cao L. Pancreatic cancer derived exosomes regulate the expression of TLR4 in dendritic cells via miR-203. Cell Immunol. 2014;292(1-2):65-9.

26. Ding G, Zhou L, Qian Y, Fu M, Chen J, Chen J, Xiang J, Wu Z, Jiang G, Cao L. Pancreatic cancer-derived exosomes transfer miRNAs to dendritic cells and inhibit RFXAP expression via miR-212-3p. Oncotarget. 2015;6(30):29877-88

27. Yan Y, Fu G, Ming L. Role of exosomes in pancreatic cancer. Oncol Lett. 2018;15(5):7479-88

28. Lundgren S, Karnevi E, Elebro J, Nodin B, Karlsson MCl, Eberhard J, Leandersson K, Jirstrom K. The clinical importance of tumour-infiltrating macrophages and dendritic cells in periampullary adenocarcinoma differs by morphological subtype. J Transl Med. 2017;15(1):152. 
29. Chen J, Li HY, Wang D, Zhao JJ, Guo XZ. Human dendritic cells transfected with amplified MUC1 mRNA stimulate cytotoxic T lymphocyte responses against pancreatic cancer in vitro. J Gastroenterol Hepatol. 2011;26(10):1509-18.

30. Liu H, Shi J, Anandan V, Wang HL, Diehl D, Blansfield J, Gerhard G, Lin F. Reevaluation and identification of the best immunohistochemical panel (pVHL, Maspin, S100P, IMP-3) for ductal adenocarcinoma of the pancreas. Arch Pathol Lab Med. 2012;136(6):601-9.

31. Pecher G, Haring A, Kaiser L, Thiel E. Mucin gene (MUC1) transfected dendritic cells as vaccine: results of a phase $1 / / 1$ clinical trial. Cancer Immunol Immunother. 2002;51(11-12):669-73.

32. Kondo H, Hazama S, Kawaoka T, Yoshino S, Yoshida S, Tokuno K, Takashima M, Ueno T, Hinoda Y, Oka M. Adoptive immunotherapy for pancreatic cancer using MUC1 peptide-pulsed dendritic cells and activated T lymphocytes. Anticancer Res. 2008;28(1B):379-87.

33. Lepisto AJ, Moser AJ, Zeh H, Lee K, Bartlett D, McKolanis JR, Geller BA, Schmotzer A, Potter DP, Whiteside T, et al. A phase I/II study of a MUC1 peptide pulsed autologous dendritic cell vaccine as adjuvant therapy in patients with resected pancreatic and biliary tumors. Cancer Ther. 2008;6(B):955-64

34. Rong Y, Qin X, Jin D, Lou W, Wu L, Wang D, Wu W, Ni X, Mao Z, Kuang T, et al. A phase I pilot trial of MUC1-peptide-pulsed dendritic cells in the treatment of advanced pancreatic cancer. Clin Exp Med. 2012;12(3):173-80.

35. Shindo Y, Hazama S, Maeda Y, Matsui H, lida M, Suzuki N, Yoshimura K, Ueno T, Yoshino S, Sakai K, et al. Adoptive immunotherapy with MUC1mRNA transfected dendritic cells and cytotoxic lymphocytes plus gemcitabine for unresectable pancreatic cancer. J Transl Med. 2014;12:175.

36. Oji Y, Nakamori S, Fujikawa M, Nakatsuka S, Yokota A, Tatsumi N, Abeno S, Ikeba A, Takashima S, Tsujie M, et al. Overexpression of the Wilms' tumor gene WT1 in pancreatic ductal adenocarcinoma. Cancer Sci. 2004;95(7):583-7.

37. Koido S, Homma S, Okamoto M, Takakura K, Mori M, Yoshizaki S, Tsukinaga S, Odahara S, Koyama S, Imazu H, et al. Treatment with chemotherapy and dendritic cells pulsed with multiple Wilms'tumor 1 (WT1)-specific MHC class I/II-restricted epitopes for pancreatic cancer. Clin Cancer Res. 2014;20(16):4228-39.

38. Mayanagi S, Kitago M, Sakurai T, Matsuda T, Fujita T, Higuchi H, Taguchi J, Takeuchi H, Itano O, Aiura K, et al. Phase I pilot study of Wilms tumor gene 1 peptide-pulsed dendritic cell vaccination combined with gemcitabine in pancreatic cancer. Cancer Sci. 2015;106(4):397-406.

39. Takakura K, Koido S, Kan S, Yoshida K, Mori M, Hirano Y, Ito Z, Kobayashi $H$, Takami S, Matsumoto Y, et al. Prognostic markers for patient outcome following vaccination with multiple MHC Class I/II-restricted WT1 peptide-pulsed dendritic cells plus chemotherapy for pancreatic cancer. Anticancer Res. 2015;35(1):555-62.

40. Tsukinaga S, Kajihara M, Takakura K, Ito Z, Kanai T, Saito K, Takami S, Kobayashi H, Matsumoto Y, Odahara S, et al. Prognostic significance of plasma interleukin-6/-8 in pancreatic cancer patients receiving chemoimmunotherapy. World J Gastroenterol. 2015;21(39):11168-78.

41. Okamoto M, Kobayashi M, Yonemitsu Y, Koido S, Homma S. Dendritic cell-based vaccine for pancreatic cancer in Japan. World J Gastrointest Pharmacol Ther. 2016;7(1):133-8.

42. Argani P, lacobuzio-Donahue C, Ryu B, Rosty C, Goggins M, Wilentz RE, Murugesan SR, Leach SD, Jaffee E, Yeo CJ, et al. Mesothelin is overexpressed in the vast majority of ductal adenocarcinomas of the pancreas: identification of a new pancreatic cancer marker by serial analysis of gene expression (SAGE). Clin Cancer Res. 2001;7(12):3862-8.

43. Thomas AM, Santarsiero LM, Lutz ER, Armstrong TD, Chen YC, Huang LQ, Laheru DA, Goggins M, Hruban RH, Jaffee EM. Mesothelin-specific CD8(+) T cell responses provide evidence of in vivo cross-priming by antigen-presenting cells in vaccinated pancreatic cancer patients. J Exp Med. 2004;200(3):297-306.

44. Eser S, Schnieke A, Schneider G, Saur D. Oncogenic KRAS signalling in pancreatic cancer. Br J Cancer. 2014;111(5):817-22.

45. Gjertsen MK, Bakka A, Breivik J, Saeterdal I, Gedde-Dahl T 3rd, Stokke KT, Solheim BG, Egge TS, Soreide O, Thorsby E, et al. Ex vivo ras peptide vaccination in patients with advanced pancreatic cancer: results of a phase I/II study. Int J Cancer. 1996;65(4):450-3.
46. Bournet B, Buscail C, Muscari F, Cordelier P, Buscail L. Targeting KRAS for diagnosis, prognosis, and treatment of pancreatic cancer: Hopes and realities. Eur J Cancer. 2016;54:75-83.

47. Poruk KE, Gay DZ, Brown K, Mulvihill JD, Boucher KM, Scaife CL, Firpo MA, Mulvihill SJ. The clinical utility of CA 19-9 in pancreatic adenocarcinoma: diagnostic and prognostic updates. Curr Mol Med. 2013;13(3):340-51.

48. Marten A, Schottker B, Ziske C, Weineck S, Buttgereit P, Huhn D, Sauerbruch T, Schmidt-Wolf IG. Increase of the immunostimulatory effect of dendritic cells by pulsing with CA 19-9 protein. J Immunother. 2000;23(4):464-72.

49. Marten A, Ziske C, Schottker B, Renoth S, Weineck S, Buttgereit $P$, Schakowski F, Klingmuller D, Scheffold C, von Rucker A, et al. Increase in the immunostimulatory effect of dendritic cells by pulsing with serum derived from pancreatic and colorectal cancer patients. Int J Colorectal Dis. 2000;15(4):197-205.

50. Cubas R, Zhang S, Li M, Chen C, Yao Q. Chimeric Trop2 virus-like particles: a potential immunotherapeutic approach against pancreatic cancer. J Immunother. 2011;34(3):251-63.

51. Chen J, Guo XZ, Li HY, Liu X, Ren LN, Wang D, Zhao JJ. Generation of CTL responses against pancreatic cancer in vitro using dendritic cells cotransfected with MUC4 and survivin RNA. Vaccine. 2013;31(41):4585-90.

52. Collignon A, Perles-Barbacaru AT, Robert S, Silvy F, Martinez E, Crenon I, Germain S, Garcia S, Viola A, Lombardo D, et al. A pancreatic tumor-specific biomarker characterized in humans and mice as an immunogenic onco-glycoprotein is efficient in dendritic cell vaccination. Oncotarget. 2015;6(27):23462-79.

53. Franceschi C, Collignon A, Isnardon D, Benkoel L, Verine A, Silvy F, Bernard JP, Lombardo D, Beraud E, Olive D, et al. A novel tumor-associated pancreatic glycoprotein is internalized by human dendritic cells and induces their maturation. J Immunol. 2011;186(7):4067-77.

54. Cappello P, Tomaino B, Chiarle R, Ceruti P, Novarino A, Castagnoli C, Migliorini P, Perconti G, Giallongo A, Milella M, et al. An integrated humoral and cellular response is elicited in pancreatic cancer by alphaenolase, a novel pancreatic ductal adenocarcinoma-associated antigen. Int J Cancer. 2009;125(3):639-48.

55. Mehrotra S, Britten CD, Chin S, Garrett-Mayer E, Cloud CA, Li M, Scurti G, Salem ML, Nelson MH, Thomas MB, et al. Vaccination with poly (IC:LC) and peptide-pulsed autologous dendritic cells in patients with pancreatic cancer. J Hematol Oncol. 2017;10(1):82.

56. Kimura Y, Tsukada J, Tomoda T, Takahashi H, Imai K, Shimamura K, Sunamura M, Yonemitsu Y, Shimodaira S, Koido S, et al. Clinical and immunologic evaluation of dendritic cell-based immunotherapy in combination with gemcitabine and/or S-1 in patients with advanced pancreatic carcinoma. Pancreas. 2012;41 (2):195-205.

57. Nakamura I, Kanazawa M, Sato Y, Irisawa A, Takagi T, Ogata T, Kashimura S, Kenjo A, Suzuki H, Shibata M, et al. Clinical evaluation of dendritic cells vaccination for advanced cancer patients at Fukushima Medical University. Fukushima J Med Sci. 2012;58(1):40-8.

58. Schnurr M, Galambos P, Scholz C, Then F, Dauer M, Endres S, Eigler A. Tumor cell lysate-pulsed human dendritic cells induce a T-cell response against pancreatic carcinoma cells: an in vitro model for the assessment of tumor vaccines. Cancer Res. 2001;61(17):6445-50.

59. Nakamura M, Wada J, Suzuki H, Tanaka M, Katano M, Morisaki T. Longterm outcome of immunotherapy for patients with refractory pancreatic cancer. Anticancer Res. 2009;29(3):831-6.

60. Bauer C, Bauernfeind F, Sterzik A, Orban M, Schnurr M, Lehr HA, Endres S, Eigler A, Dauer M. Dendritic cell-based vaccination combined with gemcitabine increases survival in a murine pancreatic carcinoma model. Gut. 2007;56(9):1275-82.

61. Bauer C, Dauer M, Saraj S, Schnurr M, Bauernfeind F, Sterzik A, Junkmann J, JakIV, Kiefl R, Oduncu F, et al. Dendritic cell-based vaccination of patients with advanced pancreatic carcinoma: results of a pilot study. Cancer Immunol Immunother. 2011;60(8):1097-107.

62. Tang ZH, Qiu WH, Wu GS, Yang XP, Zou SQ, Qiu FZ. The immunotherapeutic effect of dendritic cells vaccine modified with interleukin-18 gene and tumor cell lysate on mice with pancreatic carcinoma. World J Gastroenterol. 2002;8(5):908-12.

63. Koido S, Homma S, Kan S, Takakura K, Namiki Y, Kobayashi H, Ito Z, Uchiyama K, Kajihara M, Arihiro S, et al. Induction of antigen-specific cytotoxic T lymphocytes by fusion cells generated from allogeneic plasmacytoid dendritic and tumor cells. Int J Oncol. 2014;45(1):470-8. 
64. Chen J, Guo XZ, Li HY, Wang D, Shao XD. Comparison of cytotoxic T lymphocyte responses against pancreatic cancer induced by dendritic cells transfected with total tumor RNA and fusion hybrided with tumor cell. Exp Biol Med (Maywood). 2015;240(10):1310-8.
65. Ziske C, Etzrodt PE, Eliu AS, Gorschluter M, Strehl J, Flieger D, Messmer D, Schmitz V, Gonzalez-Carmona MA, Sievers E, et al. Increase of in vivo antitumoral activity by CD40L (CD154) gene transfer into pancreatic tumor cell-dendritic cell hybrids. Pancreas. 2009;38(7):758-65.

Ready to submit your research? Choose BMC and benefit from:

- fast, convenient online submission

- thorough peer review by experienced researchers in your field

- rapid publication on acceptance

- support for research data, including large and complex data types

- gold Open Access which fosters wider collaboration and increased citations

- maximum visibility for your research: over $100 \mathrm{M}$ website views per year

At $\mathrm{BMC}$, research is always in progress.

Learn more biomedcentral.com/submissions 